\title{
The Factors Influencing Student Satisfaction in Vietnamese Higher Education
}

\author{
Minh-Quang Duong (Corresponding author) \\ University of Social Sciences and Humanities - \\ Vietnam National University Ho Chi Minh City \\ 10-12 Dinh Tien Hoang Street, District 1, Ho Chi Minh City, Vietnam \\ E-mail: mqduong.ussh@yahoo.com
}

Received: August 24, 2015 Accepted: September 18, 2015 Published: November 19, 2015

doi:10.5296/ire.v4i1.8191

URL: http://dx.doi.org/10.5296/ire.v4i1.8191

\begin{abstract}
Student satisfaction has been considered an important factor in measuring the quality of learning approach and a key factor in the success of learning programs. The main purpose of this study investigated demographic factors affecting student satisfaction in Vietnamese higher education. In the study, I used a questionnaire to survey 618 third-year students of 24 departments and faculties at the University of Social Sciences and Humanities - Vietnam National University Ho Chi Minh City. The findings of this study showed that students were moderately satisfied with their environment campus. The study also shows that there were significant differences between student satisfaction and mother education dimension.
\end{abstract}

Keywords: satisfaction, demographic, student, higher education, Vietnam

\section{Introduction}

Educational organization is one of the most important institutional organizations of a nation. Specifically, higher education plays an important role of socio-economic development of a country (Jover \& Ones, 2009; Ministry of Education and Training (MOET), 2009). Vietnam's Law of Education states that the goal of Vietnamese higher education is to educate learners in acquiring political and moral qualities, endeavor to serve the people, professional knowledge and practical skills relevant to the educational levels, and physical health, meeting the needs of construction and defense of the fatherland (National Assembly of the Socialist Republic of Vietnam, 2005). Vietnamese higher education has gradually improved in terms of size, types of institutions, forms of training, and meeting the demand of the 
socio-economic development. However, higher education in Vietnam is facing big challenges: state governance on higher education has been slow to change, and does not facilitate or promote the improvement of training quality of whole system, nor does it encourage the creativity of academic members, education administrators, and students (MOET, 2009).

Cheng and Tam (1997) found that there are seven models for quality education, namely 1) satisfaction, 2) goal, 3) absence of problems, 4) resource-input, 5) organizational learning, 6) legitimacy, and 7) process. The satisfaction model is a good option from which strategies for quality education can be adopted and developed. Education institutions consider student satisfaction to be one of the major elements in determining the quality of open programs in today's markets (Kuo, Walker, Belland, \& Schroder, 2013). Especially universities are developing new strategies to measure quality with reference to student satisfaction (Mark, 2013). The demands and needs of students are critical for higher educational institutions if they want to be competitive (Khosravi, Poushaneh, Roozegar, \& Sohrabifard, 2013). According to Leckey and Neill (2001), any student satisfaction questionnaire should be open to access with evaluation and possible attitude of leadership regarding the steps to improve the current situation. Student satisfaction is described proportional to the students' perceived value concerning their educational institutions and experiences (Doris \& Oksana, 2009).

According to Elliott and Shin (2002), student satisfaction in higher education is defined as "the favorability of a student's subjective evaluation of the various outcomes and experiences associated with education". Student satisfaction is being shaped continually by various outcomes and their experiences in campus life. The studies of the factors influencing satisfaction of higher education students can provide relevant information about how students are thinking and what the most important areas to consider are, when it comes to student satisfaction (Pop, Bacila, Moisescu, \& Tirca, 2008). Sinclaire (2011) showed that there are three reasons for interest in student satisfaction: 1) the most important key to continuing learning, 2) positively related to retention and a decision to take one or more additional courses, and 3) represent a public relations asset for higher education institutions.

Student satisfaction is considered an important factor in measuring the quality of learning approach and a key factor in the success of learning programs. Student satisfaction is an important part of the effort to market higher education successfully (Hermans, Haytko, \& Mott-Stenerson, 2009). Student satisfaction in higher education approaches may be a tool for building a bridge between more traditional and academic views on how to improve higher education institutions, and more market-orientated perspectives (Wiers-Jenssen, Stensaker, \& Grogaard, 2002). The studies of Arambewela and Hall (2009) and Usman (2010) showed that due to an increasingly competitive, dynamic, and challenged educational environment, universities are becoming more aware of the importance of student satisfaction. Research of student satisfaction in higher education, therefore, not only enables universities to re-engineer their organizations to adapt to student needs, but also allows them to develop a system for continuously monitoring how effectively they meet or exceed student needs (O'Neill, 2003). Students' needs and expectations allow educational institutions to attract, retain quality students, and improve the quality of their programs (Elliott \& Shin, 2002). Sandhu and Kapoor (2014) recognized that student satisfaction is important and needs to be continuously 
assessed to assure quality of education experiences for students. Student satisfaction is important because it influences the student's level of motivation (Chute, Thompson, \& Hancock, 1999), which is an important psychological factor in student success (American Psychological Association, 1997).

Student satisfaction is a complex concept consisting of several dimensions (Marzo-Navarro, Iglesias, \& Torres, 2005; Richardson, 2005). Student satisfaction in higher education is influenced by a number of variables. Several past studies show that there were related factors influencing student satisfaction namely the quality of courses (Arif, Ilyas, \& Hameed, 2013; Wilkins \& Balakrishnan, 2013), effectiveness of instructional process (Elliot \& Healy, 2001; Helgesen \& Nesset, 2007), course organization (Navarro, Iglesias, \& Torres, 2005), interaction with students (O'Driscoll, 2012), the focus on student's needs (Elliot \& Healy, 2001) and campus climate (Sojkin, Bartkowiak, \& Skuza, 2012; Sultan \& Wong, 2012). According to DiBiase (2004) and Garcia-Aracil (2009), student satisfaction is a complex yet poorly articulated notion.

In this study, campus atmosphere and climate are main factors to measure student satisfaction in the University of Social Sciences and Humanities - Vietnam National University Ho Chi Minh City (USSH-VNUHCM). The findings of this study will provide instructors, administrators, educators, and other concerned entities with data regarding course satisfaction of university students toward environment campus approach. The main purpose of this study was to investigate demographic factors affecting student satisfaction in Vietnamese higher education. The study is designed to answer two questions: 1) What is the general level of student satisfaction in Vietnamese university? and 2) Do any significant differences exist in the level of faculty job satisfaction regarding demographic factors?

\section{Research Method}

\subsection{Sample}

The survey instrument was distributed to 700 students of 24 departments and faculties in the USSH-VNUHCM, of which 618 questionnaires were returned, for an $88.3 \%$ return rate, which exceeds the $30 \%$ response rate most researchers require for analysis (Dillman, 2000; Malaney, 2002). The sample of this study was drawn from 618 respondents who completed the survey instrument. Participants in this study were third-year full-time students who were studying on campus. According to Huang and Chang (2004), third-year students are considered the best population for observing student involvement and development at the university.

\subsection{Dependent and Independent Variables}

A dependent variable is a criterion or variable that is to be predicted or explained (Zikmund, 2003). Student satisfaction is the dependent variable in the study. This study used three dimensions to measure student satisfaction namely campus landscape, preserving campus, and parking on campus. The dimensions of the student satisfaction were measured with assessments using a four-point Likert scale ranging from $1=$ "very dissatisfied" to $4=$ "very satisfied". Factor analysis of the constructed dependent variable yielded adequate validity, 
showing factor loading values of the three items $(0.69-0.83)$ greater than the threshold value of 0.5 (Hair, Tatham, Anderson, \& Black, 2009). Internal consistency analysis revealed a Cronbach's coefficient (0.70) higher than the threshold value of 0.6 (Nunnally, 1978), indicating a satisfactory reliability. Total variance explained was $61.32 \%$, meeting the requirement of constructed variable for social science research (Hair et al., 2009).

An independent variable is a variable that is expected to influence the dependent variable (Zikmund, 2003). In the study, demographic factors are the independent variables. It includes gender, age, ethnic groups, family income, father and mother of education level, and discipline. The purpose of selecting these factors in this study is to identify specific groups who have low level of satisfaction with campus environment in order to provide consultation and service that can enhance satisfaction in Vietnamese higher education.

\subsection{Data Analysis Methods}

Data collection for this study was gathered from survey questionnaires administered to 618 students. After checking the precision of data entry and making codes for data analysis with the statistical analysis program, SPSS version 13.0, the following statistics were used. This study employs statistical methods of descriptive analyses, independent $t$-test and the analysis of variance (ANOVA). Descriptive analysis is conducted to understand the general level of student satisfaction in Vietnamese higher education. The independent $t$-test and ANOVA are used to examine the relationship between demographic factors and student satisfaction.

\section{Results and Discussion}

\subsection{Participants of the Study}

The findings of Table 1 show that out of the 618 third-year students at the USSH-VNUHCM, $51.6 \%$ were male and $48.4 \%$ of female students. The respondents consisted of $74.3 \%$ who were 21 years old. Regarding ethnic groups, 93.2\% of students were majority, remaining $6.8 \%$ were minority. In terms of their father education, $34.5 \%$ of students had senior high school, and $24.8 \%$ had attained junior high school. The same father education, mother education also focused on senior high school (30.4\%), and junior high school (26.1\%). For family income, $22.5 \%$ of students had under USD 1,000 and 32.8\% were over USD 3,100. Regarding student's discipline, 90.6\% were fields of social sciences, and remaining 9.4\% faculty were fields of humanities. 
Table 1. Demographic characteristics of respondents of the study

\begin{tabular}{|c|c|c|}
\hline Characteristics & $\mathrm{N}(618)$ & Percentage (\%) \\
\hline \multicolumn{3}{|l|}{ Gender } \\
\hline Female & 319 & 51.6 \\
\hline Male & 299 & 48.4 \\
\hline \multicolumn{3}{|l|}{ Age } \\
\hline 21 year-old & 459 & 74.3 \\
\hline $22-24$ & 147 & 23.8 \\
\hline Over 25 & 12 & 1.90 \\
\hline \multicolumn{3}{|l|}{ Ethnic groups } \\
\hline Majority & 576 & 93.2 \\
\hline Minority & 42 & 6.80 \\
\hline \multicolumn{3}{|l|}{ Father education } \\
\hline Elementary school & 69 & 11.2 \\
\hline Junior high school & 153 & 24.8 \\
\hline Senior high school & 213 & 34.5 \\
\hline Junior college & 57 & 9.20 \\
\hline College, university level & 121 & 19.6 \\
\hline Graduated degree & 5 & 0.80 \\
\hline \multicolumn{3}{|l|}{ Mother education } \\
\hline Elementary school & 106 & 17.2 \\
\hline Junior high school & 161 & 26.1 \\
\hline Senior high school & 188 & 30.4 \\
\hline Junior college & 55 & 8.90 \\
\hline College, university level & 104 & 16.8 \\
\hline Graduated degree & 4 & 0.60 \\
\hline \multicolumn{3}{|l|}{ Family income } \\
\hline Under USD 1,000 & 139 & 22.5 \\
\hline USD 1,001 to 1,500 & 68 & 11.0 \\
\hline USD 1,501 to 2,000 & 51 & 8.30 \\
\hline USD 2,001 to 2,500 & 46 & 7.40 \\
\hline USD 2,501 to 3,000 & 111 & 18.0 \\
\hline Over USD 3,001 & 203 & 32.8 \\
\hline \multicolumn{3}{|l|}{ Discipline } \\
\hline Social Sciences & 560 & 90.6 \\
\hline Humanities & 58 & 9.40 \\
\hline
\end{tabular}

\subsection{The General Level of Student Satisfaction at the USSH-VNUHCM}

The survey used a four-point Likert scale with responses ranging from $1=$ very dissatisfied to $4=$ very satisfied. In terms of Table 2 the findings indicated that students in 
USSH-VNUHCM were moderately satisfied with their environment campus $(M=2.78, S D=$ $0.56)$.

Table 2. The Results of Means (M) and Standard Deviations (SD) of Student Satisfaction Level at the USSH-VNUHCM

\begin{tabular}{lccc}
\hline Student satisfaction dimensions & Scores range & $M$ & $S D$ \\
\hline Average of three dimensions & & 2.78 & 0.56 \\
1. Campus landscape & $1-4$ & 2.89 & 0.71 \\
2. Preserving campus & & 2.87 & 0.66 \\
3. Parking on campus & & 2.59 & 0.80 \\
\hline
\end{tabular}

In this study, the results of descriptive analysis showed that the average of the three dimensions of student satisfaction is $69.5 \%$ (2.78/4) indicating a moderate level of job satisfaction for students in USSH-VNUHCM by comparing the scale of 4 . This finding for Vietnam is supported by studies in Germany (Gruber, Fuß, Voss \& Glaeser-Zikuda, 2010), the Czech Republic (Enache, 2011). These studies used a five-point Likert scale with responses ranging from $1=$ very dissatisfied to $5=$ very satisfied to measure the level of student satisfaction with the university. These studies showed that the average level of student satisfaction in Germany was 50\% (2.5/5), in the Czech Republic, it was 69.8\% (3.49/5). The study of student satisfaction in Bangladesh universities, Mazumder (2013) found that students of private universities are least satisfied with weekend activities, whereas students of public university are least satisfied with teachers' understanding of unique life situation and unbiased treatments factors.

Although each study used different methods, approaches and instruments to measure satisfaction for students in higher education, this study, like the other cited above, indicated that Vietnamese students were moderately satisfied with their environment campus. This means that the level of student satisfaction in the USSH-VNUHCM is comparable to those in both developing and developed countries. However, there is still much room for university administrators to improve the level of satisfaction of students in the USSH-VNUHCM.

\subsection{The Significant Different between Demographic Factors and Student Satisfaction at the USSH-VNUHCM}

This study used a combination of demographic factors namely gender, age, ethnic groups, father education, mother education, family income, and discipline which were identified as key factors to determine student satisfaction at the USSH-VNUHCM. The findings of this study show that almost demographic factors were not significant differences regarding student satisfaction, expect mother education dimension. 


\section{Macrothink}

International Research in Education

ISSN 2327-5499

2016, Vol. 4, No. 1

Table 3. The Results of $t$-test and ANOVA of Demographic Factors on Student Satisfaction at the USSH-VNUHCM

\begin{tabular}{|c|c|c|c|c|}
\hline Demographic Factors & $M$ & SD & $t$-test/ ANOVA & Post-hoc comparisons \\
\hline \multicolumn{5}{|l|}{ Gender } \\
\hline Female & 2.78 & 0.53 & \multirow{2}{*}{-0.074} & \\
\hline Male & 2.79 & 0.60 & & \\
\hline \multicolumn{5}{|l|}{ Age groups } \\
\hline 21 year-old & 2.80 & 0.54 & \multirow{3}{*}{2.768} & \\
\hline $22-24$ & 2.75 & 0.61 & & \\
\hline Over 25 & 2.44 & 0.66 & & \\
\hline \multicolumn{5}{|l|}{ Ethnic groups } \\
\hline Majority & 2.76 & 0.57 & \multirow{2}{*}{-0.199} & \\
\hline Minority & 2.80 & 0.55 & & \\
\hline \multicolumn{5}{|l|}{ Father education } \\
\hline Elementary school (ES) & 2.71 & 0.53 & \multirow{6}{*}{2.112} & \\
\hline Junior high school (JHS) & 2.84 & 0.61 & & \\
\hline Senior high school (SHS) & 2.72 & 0.56 & & \\
\hline Junior college (JC) & 2.82 & 0.53 & & \\
\hline College, university (HE) & 2.87 & 0.52 & & \\
\hline Graduated degree (PHE) & 2.40 & 0.49 & & \\
\hline \multicolumn{5}{|l|}{ Mother education } \\
\hline Elementary school (ES) & 2.68 & 0.58 & \multirow{6}{*}{$2.385^{*}$} & \\
\hline Junior high school (JHS) & 2.73 & 0.51 & & \\
\hline Senior high school (SHS) & 2.81 & 0.59 & & $(\mathrm{ES})<(\mathrm{HE})$ \\
\hline Junior college (JC) & 2.85 & 0.60 & & \\
\hline College, university (HE) & 2.90 & 0.55 & & \\
\hline Graduated degree (PHE) & 2.50 & 0.33 & & \\
\hline \multicolumn{5}{|l|}{ Family income } \\
\hline Under USD 1,000 & 2.84 & 0.61 & \multirow{6}{*}{0.334} & \\
\hline USD 1,001 to 1,500 & 2.76 & 0.59 & & \\
\hline USD 1,501 to 2,000 & 2.78 & 0.63 & & \\
\hline USD 2,001 to 2,500 & 2.79 & 0.49 & & \\
\hline USD 2,501 to 3,000 & 2.76 & 0.56 & & \\
\hline Over USD 3,001 & 2.77 & 0.53 & & \\
\hline \multicolumn{5}{|l|}{ Discipline } \\
\hline Social Sciences & 2.77 & 0.56 & \multirow[t]{2}{*}{-1.516} & \\
\hline Humanities & 2.90 & 0.59 & & \\
\hline
\end{tabular}

Note. ${ }^{*} p<.05$ 
Regarding the relationship in job satisfaction between male and female students at the USSH-VNUHCM, Table 3 shows that there were not significant differences between the satisfaction of male and female students $(t=-0.047, p>0.05)$. There was no significant difference regarding the student satisfaction with environment campus and other demographic factors such as age groups $(F=2.768, p>0.05)$, ethnic groups $(t=-0.199, p>$ $0.05)$, father education $(F=2.112, p>0.05)$, family income $(F=0.334, p>0.05)$, and discipline $(t=-1.516, p>0.05)$. Only one dimension of in this study was mother education which were significant differences between student satisfaction and mother education $(F=$ 2.385, $p=<0.05)$. Furthermore, the finding post-hoc comparison shows that mother of students holding higher education degrees $(M=2.90, S D=0.55)$ were more satisfied than those holding elementary school $(M=2.68, S D=0.58)$.

There is yet no empirical research done about the relationship between student satisfaction with environment campus and demographic factors (gender, age, father and mother education, family income, discipline) in Vietnam or even in other parts of the world. The results of this study, thus, can not be compared to results of others. Further research about the relationship between student satisfaction with environment campus and demographic factors will contribute to fill in the literature gap.

\section{Conclusion}

The student satisfaction became more important and marketing started to apply its techniques to this new market environment. Student satisfaction is considered an important factor in measuring the quality of learning approach, a key factor in the success of learning programs and a tool for building a bridge between more traditional and academic views on how to improve higher education institutions. The previous studies showed that there had measured student satisfaction relate to difference dimensions namely educational process, administrative staff, admission process, management of the faculty, image of the faculty, library, general information, cafeteria, campus climate, tutors, international cooperation, leisure activities, etc. In this study, we used dimensions of campus climate to measure student satisfaction in Vietnamese higher education.

This study has measured student satisfaction with environment campus (including campus landscape, preserving campus, and parking on campus) and investigate demographic factors (such as gender, age, ethnic groups, father and mother education, family income and discipline) affecting student satisfaction at the USSH-VNUHCM. Overall, students were moderately satisfied with their environment campus. This study also shows that there were significant differences between student satisfaction and mother education dimension. It is hoped that the barrier to the student satisfaction at the USSH-VNUHCM found in this study may be help administrator to develop and built a learning environment and climate campus that would allow higher levels of student satisfaction and contribute to filling the gap in the literature regarding Vietnam and other countries. 


\section{References}

American Psychological Association. (1997). Learner-centered psychological principles: A framework for school redesign and reform. Washington, DC.

Arambewela, R., \& Hall, J. (2009). An empirical model of international student satisfaction. Asian Pacific Journal of Marketing and Logistics, 21(4), 555-569. http://dx.doi.org/10.1108/13555850910997599

Arif, S., Ilyas, M., \& Hameed, A. (2013). Student satisfaction and impact of leadership in private universities. The TQM Journal, 25(4), 399-416. http://dx.doi.org/10.1108/17542731311314881

Cheng, Y. C., \& Tam, W. M. (1997). Multi-models of quality in education. Quality Assurance in Education, 5(1), 22-31. http://dx.doi.org/10.1108/09684889710156558

Chute, A. G., Thompson, M. M., \& Hancock, B. W. (1999). The McGraw-Hill handbook of distance learning. New York: McGraw-Hill.

DiBiase, D. (2004). The impact of increasing enrolment on faculty workload and student satisfaction over time. Journal of Asynchronous Learning Networks, 8(2), 45-60.

Dillman, D. A. (2000). Mail and internet surveys: The tailored design method. New York: John Wiley and Son.

Doris U. B., \& Oksana, W. (2009). Factors influencing faculty satisfaction with online teaching and learning in higher education. Distance Education, 30(1), 103-116. http://dx.doi.org/10.1080/01587910902845949

Elliot, K. M., \& Healy, M. A. (2001). Key factors influencing students satisfaction related to recruitment and retention. Journal of Marketing for Higher Education, 10(4), 1-12. http://dx.doi.org/10.1300/J050v10n04_01

Elliott, K. M., \& Shin, D. (2002). Student satisfaction: An alternative approach to assessing this important concept. Journal of Higher Education Policy and Management, 24(2), 197-209. http://dx.doi.org/10.1080/1360080022000013518

Enache, I. C. (2011). Customer behaviour and student satisfaction. Bulletin of the Transilvania University of Braşov, 4(53), 41-46.

Garcia-Aracil, A. (2009). European graduates' level of satisfaction with higher education. Higher Education, 57, 1-21. http://dx.doi.org/10.1007/s10734-008-9121-9

Gruber, T., Fuß, S., Voss, R., \& Glaeser-Zikuda, M. (2010). Examining student satisfaction with higher education services using a new measurement tool. International Journal of Public Sector Management, 23(2), 105-123. http://dx.doi.org/10.1108/09513551011022474

Hair, J. F., Tatham, R. L., Anderson, R. E., \& Black, W. (2009). Multivariate data analysis (6th Ed.). Upper Saddle River, NJ: Prentice Hall 
Helgesen, O., \& Nesset, E. (2007). What accounts for students' loyalty? Some field study evidence. International Journal of Public Sector Management, 21(2), 126-143. http://dx.doi.org/10.1108/09513540710729926

Hermans, C. H., Haytko, D. L., \& Mott-Stenerson, B. (2009). Student satisfaction in Web-enhanced learning environments. Journal of Instructional Pedagogies, 1, 1-19.

Huang, Y., \& Chang, S. M. (2004). Academic and co-curricular involvement: Their relationship and the best combinations for student growth. Journal of College Student Development, 45(4), 391-406. http://dx.doi.org/10.1353/csd.2004.0049

Jover, J. N., \& Ones, I. P. (2009). Higher education and socio-economic development in Cuba: high rewards of a risky high-tech strategy. Science and Public Policy, 36(2), 97-101. http://dx.doi.org/10.3152/030234209X413900

Khosravi, A. A., Poushaneh, K., Roozegar, A., \& Sohrabifard, N. (2013). Determination of factors affecting student satisfaction if Islamic Azad University. Procedia Social and Behavioral Sciences, 84, 579-583. http://dx.doi.org/10.1016/j.sbspro.2013.06.607

Kuo, Y. C., Walker, A. E., Belland, B. R., \& Schroder, K. E. E. (2013). A predictive study of student satisfaction in onlie education programs. The International Review of Research in Open and Distance Learning, 14(1), 16-39.

Leckey, J., \& Neill, N. (2001). Quantifying Quality: the importance of student feedback. Quality in Higher Education, 7(1), 19-32. http://dx.doi.org/10.1080/13538320120045058

Malaney, G. D. (2002). You still need high response rates with web-based surveys. Student Affairs On-Line, 3(1). Retrieved from http://studentaffairs.com/ejournal/Winter_2002/rates.html

Mark, E. (2013). Student satisfaction and the customer focus in higher education. Journal of Higher Education Policy and Management, 35(1), 2-10. http://dx.doi.org/10.1080/1360080X.2012.727703

Marzo-Navarro, M. M., Iglesias, M. P., \& Torres, M. P. R., (2005). A new management element for universities: satisfaction with the offered courses. International Journal of Educational Management, 19(6), 505-526. http://dx.doi.org/10.1108/09513540510617454

Mazumder, S. H. (2013). Engineering Student Satisfaction in Private and Public Universities in Bangladesh. Presented at the Proceedings of the 2013 ASEE North-Central Section Conference. American Society for Engineering Education

Ministry of Education and Training (MOET). (2009). Report on the development of higher education system, the solutions to ensure quality assurance, and improve of education quality. Retrieved from http://en.moet.gov.vn/?page $=6.7 \&$ view $=19831$

National Assembly of the Socialist Republic of Vietnam (NASRV). (2005). Education Law. Hanoi: Education Press. 
Navarro, M. M., Iglesias M. P., \& Torres P. R. (2005). A New Management Element for Universities: Satisfaction with the Offered Courses. International Journal of Education Management, 19(6), 505-526. http://dx.doi.org/10.1108/09513540510617454

Nunnally, J. C. (1978). Psychometric theory. New York: McGraw-Hill.

O'Driscoll, F. (2012). What matters most: An exploratory multivariate study of satisfaction among first year hotel/hospitality management students. Quality Assurance in Education, 20(3), 237-258. http://dx.doi.org/10.1108/09684881211240303

O'Neill, M. (2003). The influence of time on student perception of service quality: the need for longitudinal measures. Journal of Educational Administration, 41(3), 310-324. http://dx.doi.org/10.1108/09578230310474449

Pop, M. D., Bacila, M. F., Moisescu, O. I., \& Tirca, A. M. (2008). The impact of educational experience on students' satisfaction in the Romanian higher education system. International Journal of Business Research, 8(3). Retrieved from http://www.freepatentsonline.com/article/International-Journal-Business-Research/ 190617005.html

Richardson, J. T. E. (2005). Instruments for obtaining student feedback: A review of the literature. Assessment and Evaluation in Higher Education, 30(4), 387-415. http://dx.doi.org/10.1080/02602930500099193

Sandhu, D., \& Kapoor, A. (2014). Determinants of students' satisfaction towards hybrid distance learning. Indian Journal of Applied Research, 4(8), 127-128. http://dx.doi.org/10.15373/2249555X/August2014/36

Sinclaire, J. (2011). Student satisfaction with online learning: Lessons from organizational behavior. Research in Higher Education Journal, 11, 1-18.

Sojkin, B., Bartkowiak, P., \& Skuza, A. (2012). Determinants of higher education choices and student satisfaction: the case of Poland. High Education, 6(5), 565-581. http://dx.doi.org/10.1007/s10734-011-9459-2

Usman, A. (2010). The Impact of Service Quality on Students' Satisfaction in Higher Education Institutes of Punjab. Journal of Management Research, 2(2). http://dx.doi.org/10.5296/jmr.v2i2.418

Wiers-Jenssen, J., Stensaker, B., \& Grogaard, J. (2002). Student satisfaction: towards an empirical deconstruction of the concept. Quality in Higher Education, 8(2), 183-195. http://dx.doi.org/10.1080/1353832022000004377

Willkins, S., \& Balakrishnan M. S. (2013). Assesing student satisfaction in transnational higher education. International Journal of Educational Management, 27(2), 143-156. http://dx.doi.org/10.1108/09513541311297568

Zikmund, G. W. (2003). Exploring marketing research (8th Ed.). South-Western: Thomson. 


\section{Copyright Disclaimer}

Copyright reserved by the authors.

This article is an open-access article distributed under the terms and conditions of the Creative Commons Attribution license (http://creativecommons.org/licenses/by/3.0/). 